\title{
焼結前の窒化ケイ素粉体の物理・化学的評価
}

\author{
管野善則 \\ (名古屋工業技術試験所)

\section{Physico-Chemical Characteristics of $\mathrm{Si}_{3} \mathrm{~N}_{4}$ Powder before Sintering}

\author{
Yoshinori KANNO \\ $\left(\begin{array}{ll}\text { Goverment Industrial Research Institute, Nagoya } \\ 1-1, \text { Hirate-cho, Kita-ku, Nagoya-shi } & 462\end{array}\right)$
}

Physico-chemical properties of $\mathrm{Si}_{3} \mathrm{~N}_{4}$ powders were investigated with reference to grain growth behavior. The results obtained are as follows:

(1) The heat of immersion, one of the measures for the surface activity of powder, had no connection with the grain growth.

(2) The powder having a large lattice strain showed a large heat of immersion.

(3) Migration of surface atoms occurred from ca. $1450^{\circ} \mathrm{C}$, and the rearrangement of particles took place, resulting in the crystallite growth.

(4) The rate of $\beta$ phase formation was independent of the $\beta$ content in the original powder. $\quad[$ Received October 31, 1985]

Key-words : Silicon nitride powder, Activity of ceramic powder, Heat of immersion, Surface energy

\section{1. 緒 言}

新素材の注目の的として $\mathrm{Si}_{3} \mathrm{~N}_{4}, \mathrm{SiC}$ を代表とする非 酸化物系セラミックスの開発が産学官において盛んに進 められている. しかし工業材料としてのセラミックスに 対する要求はますます高度化する一方であり，七ラミッ クスが本来保有する高機能を十分に発揮していないのが 現状である. セラミックスの高機能を完全に引き出し, 信頼性のおける工業材料を供給するためには, 克服しな け机ばならない課題が多数残っている。 その中でセラ ミックスの原料粉末はその根源をなすものであり, 易焼 結性之の観点から原料粉末の特性を吟味することが最重 要課題と考えられる. 原料の吟味を終えたのちに, その 知見をもとに種々の焼結法に関する研究が始動するのが 本来の姿であると思われる.

そのような考元に基づいて, 最近, $\mathrm{Si}_{3} \mathrm{~N}_{4}, \mathrm{SiC}$ 粉体 の表面性状の物理化学的側面からのキャラクタリゼー ションや表面処理効果に関する研究が多数報告されるよ うになった ${ }^{1)-5)}$. 非酸化物系セラミックス原料の理想的 粉体の条件が Bowen らにより提唱され，一般的に次の 諸点が受け入れられている. (1) 微細粒子である, (2) 酸素を含有しない, (3) 粒径分布が狭い, (4) 等軸粒 子である, ( 5 ) 結晶相が制御されている, ( 6 ) 組織( 純 度, 化学量論性) が制御されている ${ }^{61,71}$.

本研究ではこれらの要点を更に掘り下げ, $\mathrm{Si}_{3} \mathrm{~N}_{4}$ を代 表例として焼結前の非酸化物粉体の満たすべき条件の把 握を試みたものである。

\section{1 試料}

\section{2. 実 験}

$\mathrm{Si}_{3} \mathrm{~N}_{4}$ 粉体は化学的不純物量が少なく, また $\alpha$ 相に富 む高純度品を 3 種選択し, Hermann C. Starck 製の LC10，H1 及び東芝製のものを使用した.

\section{2 粉体物性測定}

（1）浸漬熱及び比表面積

双子型恒温壁熱量計（東京理工製, TIC-22I）を用い て, $30^{\circ} \mathrm{C}$ における $\mathrm{Si}_{3} \mathrm{~N}_{4}$ 粉体のトルエンへの浸漬熱を 測定した。既知量の試料 $(50 \sim 90 \mathrm{mg})$ はガラスアンプ ル中で, $120^{\circ} \mathrm{C}, 10^{-5}$ Torr 以上の真空度で $2 \mathrm{~h}$ 脱気処理 したのち, アンプルを封じ, 熱量計にセットした. 系内 の熱平衡がえられたのち, アンプルを破壊して浸漬熱を 測定した.浸漬熱の算出に用いられる粉体の比表面積は, $200^{\circ} \mathrm{C}$ で脱気処理したのち, 液体窒素温度におけるクリ プトンガス吸着による BET 法により算出した。

（2）格子内残留ひずみ

粉体内部に残留する格子ひずみは理学電機ローターフ レックス (RU200) を用い, 加速電圧 $40 \mathrm{kV}$, 電流 $100 \mathrm{~mA}$, ゴニオ走查速度 $0.25(\% \mathrm{~min})$ の条件下でシリコンを標 準として粉末 X 線回折パターンを測定し, その回折パ ターンの幅の広がりに Hall の式を適用して算出し, 内 部蓄積エネルギーの代用とした。測定法の詳細は別報8) に記した。

\section{(3) 粒子形状}

透過型電子顕微鏡 (TEM) JEM-200CX (日本電子製) 
を用いて, $200 \mathrm{kV}, 135 \mu \mathrm{A}$ で粒子形状の観察を行った.

（4）加熱処理による粒子特性の変化

炭化ケイ素発熱体電気炉を用いて, 試料をカーボン シートに包み, カーボンるつぼ中で, アルゴン（純度 $99.9995 \%$ ）気流中， $1250^{\circ} \sim 1730^{\circ} \mathrm{C}$ の各温度に $1 \mathrm{~h}$ 保 持し, アニーリング処理をした粉体の比表面積の減少, 格子ひずみ, 結晶子径の変化及び粒子形状の変化を測 定・観察した.

\section{3 成形}

試料を $1.5 \mathrm{~g}$ 採取し，ベークライトで内張りした $11 \phi$ の金型に充てんし，0.9 t/ $\mathrm{cm}^{2}$ で予備成形したのち，ペ レットを静水圧プレス機により $2 \mathrm{t} / \mathrm{cm}^{2}$ の圧力で 1 分間 保持し，ラバープレスした。成形体の生かさ密度は試料 の直径・高さをそれぞれ，ノギス，マイクロメーターで 測定し算出した.

\section{3. 結果及び考察}

\section{1 表面活性}

粉体材料表面の活性化度をエネルギ一的に解明する手 段として熱測定が用いられ，エンタルピー変化を直接測 定する浸漬熱が多く用いられる，浸漬熱は固体を液中に 浸漬した際の固体表面の消失と同時に固-液界面の生成 に伴うエネルギー変化であり, 本研究では粉体表面の活 性化度の尺度とした。

3 種類の $\alpha-\mathrm{Si}_{3} \mathrm{~N}_{4}$ 粉体のトルエン液中における浸漬熱 を測定し，恒温壁熱量計における $\Delta T-t$ 曲線を図1に 示し, 更に浸漬熱及び比表面積の值を表 1 に示した.

図 1 より, 各々の $\alpha-\mathrm{Si}_{3} \mathrm{~N}_{4}$ の発熱パターンは特徴的な 変化を示し, LC10においてはパターンから判断すると
瞬間可逆吸着による発熱のみが観察され，素早く熱平衡 に達した。一方東芝製の粉体の場合, 初期の瞬間可逆吸 着による発熱は微少であるが，遅い活性化吸着がじわじ わ進行し，結果的に高い浸漬熱の值を示した。H1にお いては瞬間可逆吸着と活性化吸着の重祆合わせによる発 熱パターンを示した。結果的に, 浸漬熱の序列は東芝 $>\mathrm{H} 1>\mathrm{LC} 10$ の順と考えられ，また比表面積の序列は LC10>H1>東芝であった.

\section{2 格子ひずみと結晶子径}

一般に粉体の特徴の一つは粉体の生成過程に強く依存 する多くの久宿を含んでいることであり，非常に大きな 構造上のひずみをもつことである.この構造ひずみは粉 体の物性值に少なからず影響を与え，粉体特性を評価す る場合には構造ひずみの度合を示すことが必要である。

ここでは粉体の構造上のひずみを表すパラメーターとし て格子ひずみを採用した。

Hall プロットより算出した格子ひずみと結晶子径を 表 1 に併記した。 結晶子径の大小は BET による比表面 積の大小とよく対応し, 格子ひずみの大きい試料ほど高 い浸漬熱の值が得られ, 表面の活性化度が高くなる傾向 がみられた。

一般に, X 線で得られるデー夕は表面層より深く入っ た領域の情報であり，浸漬熱のデー夕は表面第 1 層の情 報と考えられる。したがって上記の格子ひずみの序列と 浸漬熱の序列との対応関係は表面層近傍の乱れが，表面 第 1 層より内部にある程度連続的に変化していることを 暗示している.

\section{3 加熱による粉体性状の変化}

焼結性に関する基礎資料を蓄積するために，末成形粉

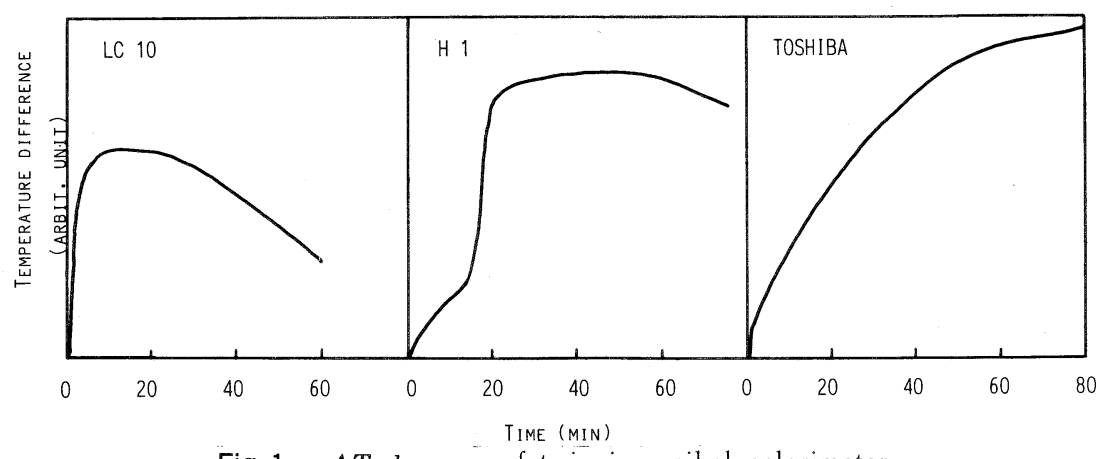

Fig. 1. $\Delta T-t$ curve of twin isoperibal calorimeter.

Table 1. Specific surface area, heat of immersion into toluene, and crystallite size and lattice strain determined by the Hall's equation.

\begin{tabular}{lccccc}
\hline \hline $\begin{array}{l}\text { ORIGINAL SPECIFIC SURFACE } \\
\text { POWDER }\end{array}$ & HEAT OF $\left(\mathrm{M}^{2} / \mathrm{G}\right)$ & $\begin{array}{c}\text { IMMERSION } \\
\left(\mathrm{J} / \mathrm{M}^{2}\right)\end{array}$ & $\begin{array}{c}\text { CRYSTALLITE } \\
\text { SIZE (NM) }\end{array}$ & $\begin{array}{c}\text { LATTICE } \\
\text { STRAIN ( - ) }\end{array}$ \\
\hline LC 10 & 14.24 & 0.9 & 94 & $\approx 0$ \\
H 1 & 8.89 & 2.4 & 102 & $6 \times 10^{-5}$ \\
TOSHIBA & 7.93 & 3.6 & 107 & $7.9 \times 10^{-4}$ \\
\hline
\end{tabular}




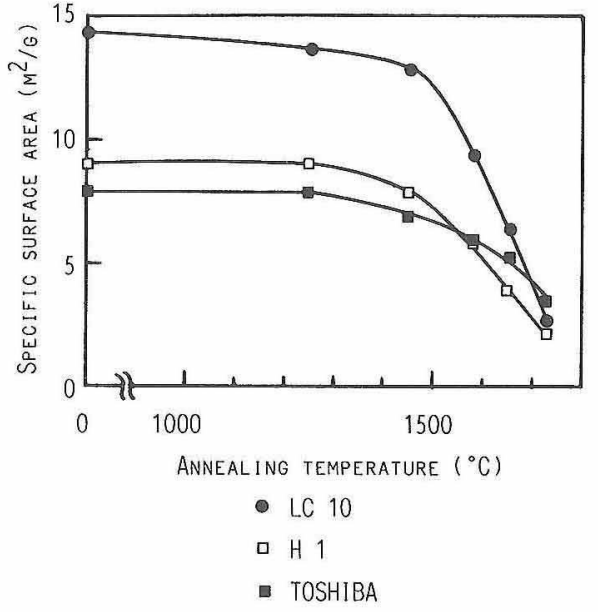

Fig. 2. Variation of specific surface area with anneal. ing temperature.

体の加熱処理による性状変化を追求した，

図2にアニーリング処理によるクリプトン吸着より算 出した比表面積の変化を示した。 3 種の $\alpha-\mathrm{Si}_{3} \mathrm{~N}_{1}$ ともに $1450^{\circ} \mathrm{C}$ 付近加急激な此表面積の減少を示し, この温 度で著しい表面付近での物質移動の助長がみられた。ま た比表面積の娍少速度は LC10 が最大であり, 以下, H1, 東芝の順であった。この比表面積の隇少率と表 1 の浸漬 熱あるいは格子ひずみの大きさとの間には相関関係が存 在せず，未成形粉体の粒成長を律しているパラメーター

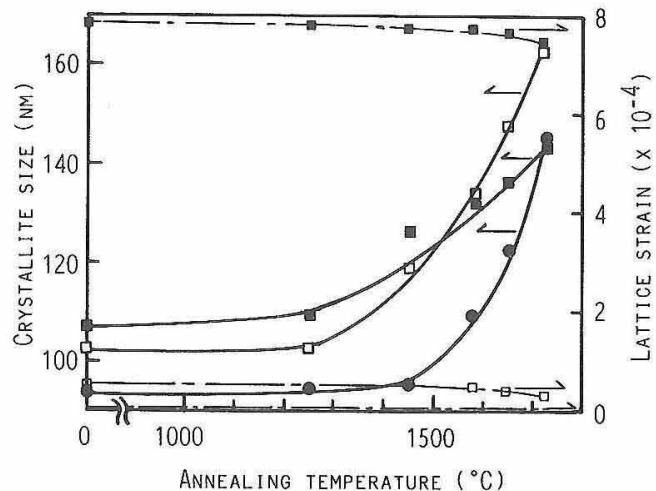

- LC 10

ㅁ $\mathrm{H} 1$

- TOSHIBA

Fig. 3. Variation of lattice strain and crystallite size with annealing temperature.

の把握が不充分である。

図３にアニーリング温度による結晶子径と格子ひずみ の変化を示す.結晶子径の変化は図 2 に示した比表面積 の変化よよく対応し， $1450^{\circ} \mathrm{C}$ 付近より著しく結晶子の 成長がみられる。しかし，一方で格子ひずみの緩和は起 こりにくく，この事実が図 2 に示した未成形粉体の粒成 長と内部残留ひずみとの間に相関関係が認められない理 由を裏付けている，しかし前記したように依然として充 てん粉末の粒成長速度を律している粉体特性を抽出する

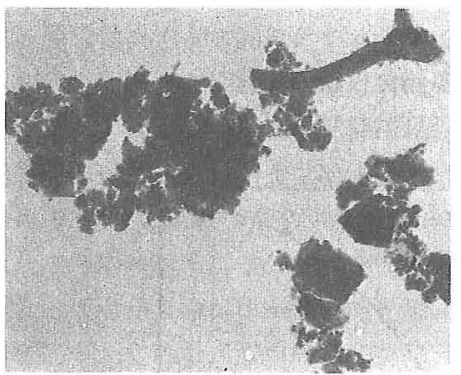

LC10



$\mathrm{H} 1$

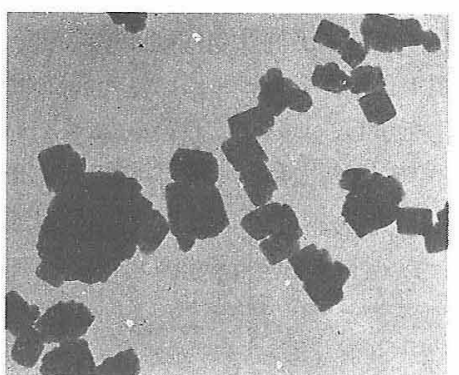

TOSHIBA
$1 \mu \mathrm{m}$

Fig. 4. Microphotograph of TEM image for as-received powder.

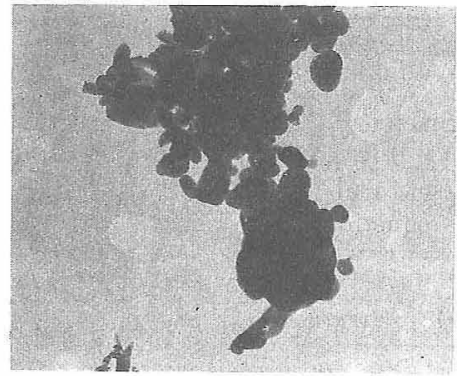

LC10

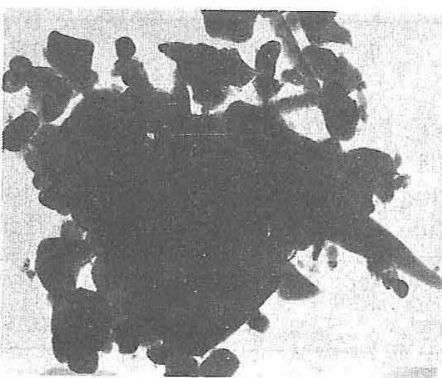

$\mathrm{H} 1$

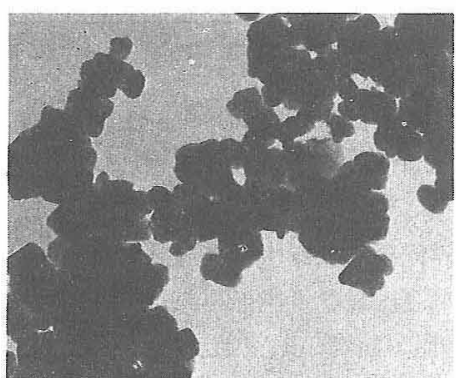

TOSHIBA

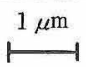

Fig. 5. Microphotograph of TEM image for annealed powder at $1650^{\circ} \mathrm{C}$ for $1 \mathrm{~h}$ under Ar flow. 


\section{ことはできていない.}

$\mathrm{TEM}$ 観察より 3 種の $\alpha-\mathrm{Si}_{3} \mathrm{~N}_{4}$ 粉体の形状, 及び $1650^{\circ} \mathrm{C}-1 \mathrm{~h}$, アルゴン気流中で加熱処理した粉体の形状 の変化をそれぞれ図4, 図 5 に示す。

LC10，H1 は針状粒子や角形粒子をはじめとして， 不規則形状粒子の集合体からなり，微細な 1 次粒子が多 数存在し, 特にLC10においては超微粒子とみなされ る部分が多くみられる。

3 種類の $\mathrm{Si}_{3} \mathrm{~N}_{4}$ において, LC10 の比表面積が最大な のは，この超微粒子の存在によるものと考えられる．東 芝製の粉体の場合，比較的形状が整っており，均一角形 粒子の集合体であり，大きな 2 次粒子が多数みられた。 また，超微粒子もみられず，小さな比表面積を裏付けて いる.

これらの試料を $1650^{\circ} \mathrm{C}$ でアニールした場合，図 5 に 示したように粒子形状は 3 種類ともに丸みをおび，表面 付近での物質移動が進行したことを示している。 LC10 と $\mathrm{H} 1$ においては，H1 の方にまだ針状粒子が多数みら れた。東芝製の粉体の場合，ところよ゙ころに角形粒子が 認められ， $1650^{\circ} \mathrm{C}$ においても存在するこの角形粒子が 図 2 に示した BET 表面積の減少量が小さかった事実を 裏付けている.

本項で議論した粉体の加熱処理による性状変化を追求 する場合，一般的には結晶転移を伴わない条件下で粉体 性状の変化を追跡した方がより箃密な考察が可能と考え られる. しかし $\mathrm{Si}_{3} \mathrm{~N}_{4}$ の場合には，加熱処理により $\alpha$ 型から $\beta$ 型への転移が生ずることが知られており，こ こでは便宜上 $\alpha-\mathrm{Si}_{3} \mathrm{~N}_{4}$ 粉体の特性変化として捕らえた。

図6に各々の加熱温度で $1 \mathrm{~h}$ 保持した際の $\alpha, \beta$ 分率



Fig. 6. Variation of $\alpha$-percentage with annealing temperature.
に占める $\alpha$ 率の変化を $\alpha-\beta$ 検定曲線 ${ }^{9)}$ より算出し示し た. $\mathrm{Si}_{3} \mathrm{~N}_{4}$ の $\alpha \rightarrow \beta$ 相転移に関しては数多くの研究例が 報告され ${ }^{10), 11)}$, 無機材質研究所の研究グループにより単 結晶を用いた実験から， $\alpha \rightarrow \beta$ 相転移はその転移が予想 された温度近辺で, 昇華分解する一歩手前まで加熱され たとしても, 低温型 $\alpha-\mathrm{Si}_{3} \mathrm{~N}_{4}$ の結晶構造を変えることな く堅持し，加熱処理がある限界点に至ると急激に昇華分 解すること, そしてこの分解に至るまでの過程では, 低 温型から高温型への固体内の相転移が存在しないことが 明らかにされた ${ }^{12)}$.

図 6 の結果は,その知見を裏付けており, 粉末の場合 でも図 2 , 図 3 に示したように焼結のごく初期段階にお ける表面付近での物質移動が進行しても, 更に結晶子の 成長がうながされても $\alpha \rightarrow \beta$ 相転移が生ぜず， $\alpha$ 型のま ま表面移動及び再配列をして粒成長をなすと考えられ る.この点に関しては高圧力下における山田 ${ }^{13)} ら の$ 知見 と同様であった。また供給された状態における $\beta$ 相含 有率の差は $\alpha \rightarrow \beta$ 相転移に影響を及ぼすことがないとみ なされ，化学的不純物量が同一であり，加熱処理条件が 同一ならば $\alpha \rightarrow \beta$ 相転移の開始温度は実験誤差内に納 まってしまうのではないかと推量される. また $\beta$ 相析 出速度を律するのは一度昇華分解した蒸気相の濃度によ るのではないかと考えられる。

ここで充てん粉末の粒成長と粉体表面層の活性との関 係について簡単に触れてみよう。本研究では粒成長速度 の序列は $\mathrm{LC} 10>\mathrm{H} 1>$ 東芝と得られたが，この序列は 粉体表面層の活性化度の序列とは一致していない。これ



彼らは $\mathrm{BeO}$ 粉末の湿潤熱 $\left(\Delta H_{i}\right)$ と焼結性との関係 について論じ, $\Delta H_{i}$ の高い方は焼結性が悪いとしてい る.この場合にも，焼結に寄与しない不安定な高いポテ ンシャルエネルギーをもつサイトからの発熱を計算した ために生じたものと推察される．したがって，焼結性の 観点から粉体表面活性化度をみる場合, サイト選択性を 考慮し，更に検討を加える必要がある。

\section{4 成形性}

各試料につき 10 個のペレットを作製し，算出した成 形体の生かさ密度の平均值を表 2 に示した。生かさ密度 の序列は H1>LC10>東芝となり，東芝粉体の場合， 他の 2 種のものより極端に生かさ密度が小さい.この理 由は図 4 に示したTEM 像より明らかなように, 角形

Table 2. Relative density of green body rubberpressed at $2 \mathrm{t} / \mathrm{cm}^{2}$.

\begin{tabular}{lc}
\hline \hline & RELATIVE DENSITY $(\%)$ \\
\hline LC 10 & 57.1 \\
H 1 & 60.6 \\
TOSHIBA & 50.2 \\
\hline
\end{tabular}


粒子のために充てん密度が上がらなかったと思われる。 また LC10 が H1 よりわずかに小さな值を示したのは恐 らく超微粒子の含有率が高いことによるものと考えられ る.

焼結は化学反応と物理反応の並行反応であると考えら れる. 各々の反応に関係する諸因子の中の一つとして, 化学反応に関与する因子は粉体表面層の活性化度であ り, 物理反応に関与するのは成形体のかさ密度, 換言す れば着目粒子 1 個当たりの配位数が 1 例として挙げられ る. 特に共有結合性の強い化合物の場合, 極端に原子の 移動度が小さいため, 拡散距離を短くすることが重要で あり，そのためには成形体の充てん密度を上げることが 要求される. 特に焼結温度手前の加熱処理で粉体表面層 の活性化度が消失してしまう場合，ち密化に大きく貢献 するのは物理反応に関与する因子の一つである成形体密 度と考えられる。したがって, 今後理論密度に近い $\mathrm{Si}_{3} \mathrm{~N}_{4}$ 焼結体を得るためにも，微粒子を用い，成形体密 度をいかに上げるかは解決すべき重要な因子の一つであ ろう。

\section{4. 総 括}

セラミックスが本来保有する高機能を十分に引き出す ためには，その根源である粉体の特性を易焼結性との関 係から吟味することが必要である。本研究では $\mathrm{Si}_{3} \mathrm{~N}_{4}$ 粉 末の特性と充てん粉末と粒成長との関係を把握して, 焼 結性に寄与する粉体特性の抽出を試みた。化学的不純物 量の少ない, $\alpha$ 相に富む試料 3 種を選択し, その物理・ 化学的特性及び加熱処理によるその変化を追求し, 以下 の事項が明らかとなった。

（1）粉体表面活性化度を示す浸漬熱の值そのものは 粒成長速度と対応しない。

（2）格子ひずみの大きい粉体ほよ゙浸漬熱が高く，表
面層近傍における乱れは表面と内部である程度連続的に 変化する.

(3) $\alpha-\mathrm{Si}_{3} \mathrm{~N}_{4}$ は $1450^{\circ} \mathrm{C}$ 付近から急激に比表面積が 減少し,この温度で著しい表面付近での物質移動の助長 がみられた。しかし $\beta$ 化は進行しない。

（4） $\alpha \rightarrow \beta$ 相転移は粉末の場合でも加熱処理の，あ る限界まで起こらず， $\alpha$ 型のまま表面移動や再配列をし て粒成長する.また含有する $\beta$ 相率は $\alpha \rightarrow \beta$ 相転移に影 響を及ぼさない。

（5）焼結性の観点から表面エネルギーをみる場合， サイト選択性を考慮する必要がある。

（6）均一な角形粒子の成形性は不規則形状粒子のそ れより劣る。

謝辞ここに記した知見は, 科学技術庁振興調整費によ る研究 “表面・界面の制御による無機材料の高性能化に関する 研究”で得られたものである．助成に謝意を表する。

\section{文献}

1）李 潔, 服部 信, 䉑協, 94, 264-47 (1986).

2) 宇津木 弘, 遠藤 敦, 鈴木 昇, 小野和也, 粉体およ び粉末治金，31，260-65（1984）。

3）管野善則，今井久雄，窯協，92，600-03 (1984)。

4）管野善則, 窯協, 93, 561-65 (1985).

5) Y.Kanno, Pow. Tech., 44, 93-97 (1985).

6) 宗宮重行，エレクトロニクセラミクス，No. 3，63-71 (1985).

7) 木島式倫, 材料科学, 19, 12-19 (1982)。

8）管野善則, 粉体工学会誌, 21, 697-98 (1984).

9）鈴木一夫，管野善則，窯協，92，101-02（1984）.

10) E. T. Turkdogan, P. M. Bills and V. A. Tippett, J. Appl. Chem. , 8, 296-302 (1958).

11) P.Popper and S. N. Ruddlesden, Trans. Brit. Ceram. Soc., 60, 603-26 (1961).

12）窒化ケイ素に関する研究，無機材研研究報告書第 13 号, 34-38 (1977).

13）山田哲夫, 島田昌彦, 小泉光恵, 窯協, 92, 118-23 (1984)

14）池上隆康, 松田伸一, 鈴木弘茂, 窯協, 81, 322-27 (1973) 